\title{
Synthesis of Silk Silver Nanoparticles form Silkworm Cocoons and Their Antibacterial Activity on Methicillin Resistant Staphylococcus aureus (MRSA) and Escherichia coli
}

Harinatha Reddy $A^{1 *}$ and Venkatappa $B^{2}$

${ }^{1}$ Department of Life Sciences, Christ University, Bangalore-560029, Karnataka, India

${ }^{2}$ Department of Microbiology, Sri Krishnadevaraya University, Anantapur-515 003, Andhra Pradesh, India

\begin{abstract}
In this study, silk protein was used for the synthesis of silver nanoparticles (AgNPs). The freshly prepared silk colloid solution is color less, after $24 \mathrm{~h}$ incubation with $\mathrm{AgNO}_{3}$, the color change was observed from colourless to brown colour. The AgNPs were characterized by UV-visible spectrophotometer. The colloid solution of silk showed an absorption peak between $250-280 \mathrm{~nm}$, after $24 \mathrm{~h}$ of incubation with $\mathrm{AgNO}_{3}$ the absorbance peak was centered near $420 \mathrm{~nm}$ indicating the reduction of silver nitrate into silver nanoparticles by silk protein. Bacterial sensitivity to silver nanoparticles is commonly tested using a well diffusion assay. MRSA and $E$. coli were isolated from hospital soil samples. S. aureus and E. coli identified by with by microscopic and biochemical tests. MRSA identified in the selected isolates by the KirbyBauer disk diffusion test with vancomycin $(30 \mu \mathrm{g})$, ampicillin $(10 \mu \mathrm{g})$, oxacillin $(1 \mu \mathrm{g})$ and cefoxitin $(30 \mu \mathrm{g})$ antibiotics using Mueller-Hinton agar plates. The diameter of inhibition zone reflects the magnitude of susceptibility of microbes. The strains susceptible to silk silver nanoparticles exhibited larger zone of inhibition, whereas resistant strains exhibit smaller zone of inhibition. According to zone of inhibition Methicillin-resistant Staphylococcus aureus (MRSA) and E. coli exhibited sensitivity towards sericin silver nanoparticles.
\end{abstract}

Keywords: Silk; Silver nano particles (AgNPs); Silk worms; Methicillin-resistant Staphylococcus aureus (MRSA); E. coli

\section{Introduction}

Silk is a protein produced by Bombyx mori during spinning of cocoon; it consists mainly of two proteins, sericin and fibroin. Silk filament is a double strand of fibroin, held together by a protein called silk sericin [1]. Fibroin being the structural center of the silk consists of glycoproteins expressed in the middle of the silk gland. Fibroin protein used in textile industry and sericin protein considered as a waste product from the textile industry. Fibroin and sericin has medical and pharmaceutical applications. Sericin-containing food relives constipation, suppresses development of colon tumors and bowel cancer [2]. Sericin inhibits lipid peroxidation in in vitro rat brain homogenate [3] and inhibits UV-induced apoptosis in human skin keratinocytes [4].

The silk fiber protein is synthesized by silk gland cells and stored in the lumen of the silk glands. Subsequently, it is converted into silk fibers. When the silkworms secrete the liquid silk during the spinning, it passes through the anterior gland and expelled out through the spinneret opening [5]. Sericin is insoluble in cold water, however, it is easily hydrolyzed, where by the long protein molecules break down to smaller fractions, which are easily dispersed or solubilised in hot water [6]. Sericin protein is useful because of its special properties viz., resists oxidation, anti-bacterial, UV resistant and absorbs and releases moisture easily, inhibits activity of tyrosine and kinase etc. Silk proteins are natural polymers and are biodegradable with reactive functional groups that open up possibility to be cross linked with other polymers to be used in controlled delivery [7]. Recently, Silk sericin has been widely used in biomaterial applications due to its biocompatibility, biodegradability and anti-oxidative and bioactive activities [8].

S. aureus is a gram positive, facultative anaerobic bacteria and common cause of skin infections, respiratory infections, bone infections, blood infections and pneumonia on humans. S. aureus opportunistic pathogen found in the skin and nose as part of human normal flora. There are five species to $S$. aureus, S. epidermidis, $S$. saprophyticus, S. haemolyticus, and S. hominis consider as potential human pathogens in this genus, but among this pathogenic bacteria $S$. aureus is the most problematic, causes skin, joint and blood infections in humans. Methicillin antibiotic was first used to treat $S$. aureus in 1959 and just after 2 years of use, methicillin-resistant Staphylococcus aureus (MRSA) strains had be isolated [9]. In MRSA stains mecA gene encodes a protein, penicillin-binding protein (PBP2a), which cannot allow the binding of $\beta$-lactam antibiotics such as such as penicillin, vancomycin, ampicillin, oxacillin and cefoxitin and in prevents the disruption of cell wall formation by these antibiotics, there by MRSA strains have resistance to many commonly used $\beta$-lactam antibiotics. Vancomycin has been the standard hospital treatment for the past 40 years, but vancomycin resistant isolates of S. aureus have emerged [10]. In the present study we report that activity of silk silver nanoparticles against MRSA and E. coli bacteria. Now a days nanoscience and nanotechnology used to treat, and prevent various bacterial, fungal and protozoa diseases in human life.

\section{Materials and Methods}

\section{Collection of silkworm cocoons}

The silkworm CSR-4 cocoons were collected form Sericulture department at Sri Krishnadevaraya University, Anantapur.

*Corresponding author: Harinatha Reddy A, Department of Life sciences, Christ University, Hosur Road, Bengaluru, Karnataka-560029, India, Tel: 917026474302 E-mail: harinathareddy.a@christuniversity.in

Received: July 23, 2017; Accepted: August 14, 2017; Published: August 21 2017

Citation: Harinatha Reddy A, Venkatappa B (2017) Synthesis of Silk Silver Nanoparticles form Silkworm Cocoons and Their Antibacterial Activity on Methicillin Resistant Staphylococcus aureus (MRSA) and Escherichia coli. J Nanomed Nanotechnol 8: 453. doi: 10.4172/2157-7439.1000453

Copyright: ( 2017 Harinatha Reddy A, et al. This is an open-access article distributed under the terms of the Creative Commons Attribution License, which permits unrestricted use, distribution, and reproduction in any medium, provided the original author and source are credited. 


\section{Preparation of sericin colloidal solution}

The silkworm cocoons were cut into small pieces. The solution of silk was prepared by boiling $20 \mathrm{gm}$ of the cocoon pieces in $200 \mathrm{ml}$ of distilled water for $20 \mathrm{~min}$. After cooling, the solution was filtered using whatman filter paper. The freshly prepared silk colloidal solution showed absorption peak between 250-280 $\mathrm{nm}$ [11].

\section{Estimation of protein in sericin colloidal solution}

The total protein content was determined with Folin Ciocalteau's reagent according to the Lowry et al. [12].

\section{Biosynthesis of sericin silver nanoparticles}

The crude extract of silk was used for experiments. Five $\mathrm{ml}$ of the crude extracts of silk was added to a conical ask containing $5 \mathrm{ml}$ of 3 $\mathrm{mM}$ aqueous $\mathrm{AgNO}_{3}$ solution heated at $65^{\circ} \mathrm{C}$ with continuous stirring. The silver ions were reduced to silver nanoparticles (AgNPs) within few minutes by silk extract. The conversion of solution color showed the formation of silver nanoparticles by observing color change from colorless to brown color. The synthesized silver nano particles were analyzed for UV-Visible spectroscopic studies after time duration of $24 \mathrm{hrs}$. The synthesized silver nano particles colloidal solution showed strong absorption between 400 and $420 \mathrm{~nm}$.

\section{Collection of microorganisms}

MRSA and E. coli were isolated from hospital soil samples. The soil samples were cultured on selective and differential media (Mannitol salt agar media and Eosin methylene Blue agar) and incubated at $37^{\circ} \mathrm{C}$ for 48 hours. S. aureus and E. coli identified by microscopic and biochemical tests. MRSA identified in the selected isolates by the Kirby Bauer disk diffusion test with vancomycin $(30 \mu \mathrm{g})$, ampicillin $(10 \mu \mathrm{g})$, oxacillin $(1 \mu \mathrm{g})$ and cefoxitin $(30 \mu \mathrm{g})$ antibiotics using Mueller-Hinton agar plates.

\section{Inhibition zone assay}

In vitro antibacterial activity was evaluated by agar well diffusion method using Mueller Hinton Agar (MHA) [13]. Working stock was prepared as $1 \mathrm{ml}$ of each bacterial strain was initially inoculated in 100 $\mathrm{ml}$ of sterile Mueller Hinton broth and incubated for $37^{\circ} \pm 1^{\circ} \mathrm{C}$ for $24 \mathrm{hr}$ respectively. Then $0.2 \mathrm{ml}$ of the each test organisms from the working stock were seeded into $100 \mathrm{ml}$ sterile MHA medium and cooled to $48^{\circ} \mathrm{C}$ to $50^{\circ} \mathrm{C}$ in a sterile Petri dish respectively. When the MHA solidifies, six holes of uniform diameter $(7 \mathrm{~mm}$ ) were made using sterile aluminium borer. Then, $70 \mu \mathrm{l}$ of standard silk silver nanoparticles solution (10, $20,30,40,50 \mu \mathrm{g} / \mathrm{ml}$ ) respectively and control (Ciprofloxacin $25 \mathrm{mg} /$ $\mathrm{ml}$ ) were placed in each hole separately under aseptic condition. All the bacterial plates were then incubated at $37^{\circ} \pm 1^{\circ} \mathrm{C}$ for $18 \mathrm{hr}$ and the zone of inhibition was measured (including the diameter of the bore ( 7 $\mathrm{mm})$ ) and the results were recorded.

\section{Results and Discussion}

The freshly prepared silk colloid solution is color less, after $24 \mathrm{~h}$ incubation with $\mathrm{AgNO}_{3}$, the color change was observed from colorless to brown color (Figure 1). The AgNPs were characterized by UVvisible spectrophotometer. The colloid solution of silk showed an absorption peak at $250-280 \mathrm{~nm}$, after $24 \mathrm{~h}$ of incubation with $\mathrm{AgNO}_{3}$ the absorbance peak was centered near $420 \mathrm{~nm}$ indicating the reduction of silver nitrate into silver nanoparticles by fibroin and sericin proteins (Figure 2).

Bacterial sensitivity to silver nanoparticles tested using a well

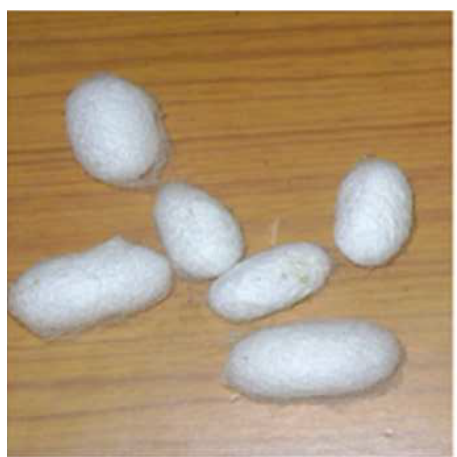

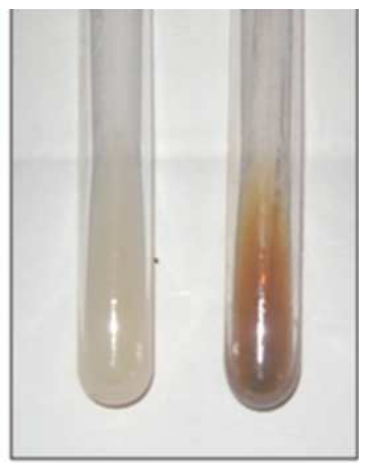

B
Figure 1: (A) Silkworm cocoons (B) The silk colloid solution colour change from colourless to brown colour after $24 \mathrm{~h}$ of incubation with $\mathrm{AgNO}_{3}$.

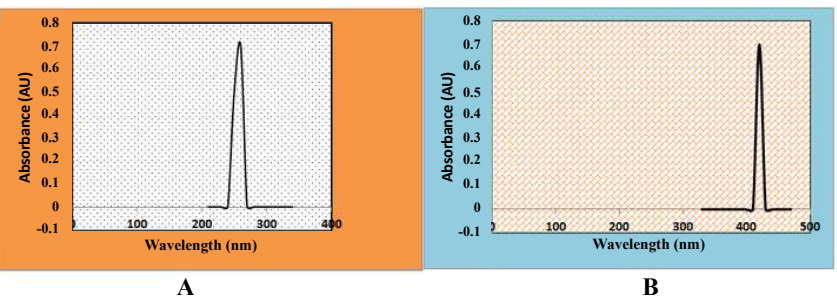

Figure 2: (A) UV-Visible spectroscopic absorption peak of silk colloid solution at $276 \mathrm{~nm}$. (B) UV-Visible spectroscopic absorption peak of silk silver nanoparticles at $420 \mathrm{~nm}$.

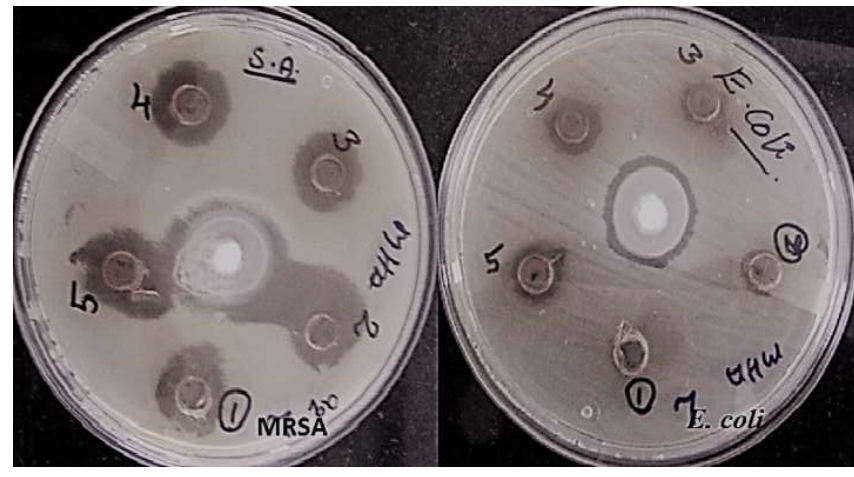

Figure 3: Antibacterial activity of silk silver nanoparticles on (A) Methicillinresistant Staphylococcus aureus (MRSA) (B) E. coli.

diffusion assay. The diameter of inhibition zone reflects the magnitude of susceptibility of microbes. The strains susceptible to silk silver nanoparticles exhibited larger zone of inhibition, whereas resistant strains exhibit smaller zone of inhibition. According to zone of inhibition S. aureus and E. coli exhibited the highest sensitivity toward silk silver nanoparticles (Figure 3). The microbial property of silver nanoparticles was analyzed by measuring the inhibition zone (Table 1). The synthesized silk silver nanoparticles show an effective antibacterial activity against pathogens of Gram positive and Gram negative bacteria. The result suggests that silver nanoparticles undergo an interaction with bacterial cell and displayed the strong action against MRSA and E. coli. The antimicrobial properties of silver compounds and silver ions had been historically recognized and applied in a wide range of applications from disinfecting medical devices and for the treatment of 
Citation: Harinatha Reddy A, Venkatappa B (2017) Synthesis of Silk Silver Nanoparticles form Silkworm Cocoons and Their Antibacterial Activity on Methicillin Resistant Staphylococcus aureus (MRSA) and Escherichia coli. J Nanomed Nanotechnol 8: 453. doi: 10.4172/2157-7439.1000453

Page 3 of 3

\begin{tabular}{|c|c|c|c|c|c|c|c|}
\hline \multirow[t]{2}{*}{ S. No } & \multirow[t]{2}{*}{ Microorganisms } & \multicolumn{6}{|c|}{ Zone of inhibition measured in $\mathrm{mm}(\mu \mathrm{g} / \mathrm{ml})$} \\
\hline & & Ciprofloxacin $(25 \mathrm{mg} / \mathrm{ml})$ & 10 & 20 & 30 & 40 & 50 \\
\hline 1 & MRSA & 26 & 11 & 16 & 18 & 20 & 24 \\
\hline 2 & E. coli & 23 & 10 & 13 & 16 & 18 & 21 \\
\hline
\end{tabular}

Table 1: Antibacterial activity of silk silver nanoparticles on Methicillin-resistant Staphylococcus aureus (MRSA) and E. coli.

water. AgNPs is currently used to control bacterial growth in a variety of applications, including dental work and burn wounds. In fact, it is well known that Ag ions and Ag-based compounds are highly toxic to microbes, showing strong biocidal effects [14].

In this experiment AgNPs were showed high antibacterial activity on Gram-positive methicillin-resistant Staphylococcus aureus bacteria and Gram-negative E. coli bacteria. AgNPs seem to be alternative antibacterial agents to antibiotics and have the ability to overcome the bacterial resistance against antibiotics. When $E$. coli cells treated with AgNPs, the AgNPs were accumulated in the cell wall of bacteria and induce formation pores in the bacterial cell walls, eventually leading to cell death [15]. The positively charged silver nanoparticles bind to the negatively charged polyanionic backbones of teichoic acids and cell wall glycopolymers, leading to structural strain and permeability of the bacterial cell wall [16].

\section{Acknowledgement}

The authors express their sincere thanks to all the authors in reference list for support to this research.

\section{References}

1. Padamwar MN, Pawar AP (2004) Silkworm sericin and its applications: A review. Journal of Scientific and industrial research 63: 323-329.

2. Joseph B, Raj SJ (2012) Therapeutic applications and properties of silk proteins from Bombyx mori. Frontiers in Life Science 6: 55-60.

3. Kato N, Sato S, Yamanaka A, Yamadam H, Fuwa N, et al. (1998) Silk protein, sericin, inhibits lipid peroxidation and tyrosinase activity. Biosci Biotechnol Biochem 62: 145-147.

4. Dash R, Mandal M, Ghosh SK, Kundu SC (2008) Silk sericin protein of tropical tasar silkworm inhibits UVB-induced apoptosis in human skin keratinocytes. Mol Cell Biochem 311: 111-119.
5. Shimizu M (2000) Structural basis of silk fibre; in structure of silk yarn. Biologica and physical aspects New Delhi, India.

6. Gulrajani ML (1988) Degumming of silk in silk dyeing printing and finishing Department of Textile Technology Indian Institute of Technology, New Delhi, India.

7. Mondal M, Trivedy K, Nirmal Kumar S (2007) The silk proteins, sericin and fibroin in silkworm, Bombyx mori Lin., - Review. CJES 5: 63-76.

8. Aramwit P, Bang N, Ratanavaraporn J, Ekgasit S (2014) Green synthesis of silk sericin-capped silver nanoparticles and their potent anti-bacterial activity. Nanoscale Res Lett 9: 79.

9. Deurenberg RH, Vink C, Kalenic S, Friedrich AW, Bruggeman CA, et al. (2007) The Molecular Evolution of Methicillin-resistant Staphylococcus aureus. Clin Microbiol Infect. 13: 222-235

10. Moreillon $P$ (2008) New and emerging treatment of Staphylococcus aureus infections in the hospital setting. Clin Microbiol Infect 3: 32-41.

11. Bhat PN, Nivedita S, Subrata R (2011) Use of sericin of Bombyx mori in the synthesis of silver nanoparticles, their characterization and application. IJFTR 36: 168-171.

12. Lowry OH, Rosebrough NJ, Farr AL, Randall RJ (1951) Protein measurement with Folin Phenol reagent. J Biol Chem 193: 265-275.

13. Bauer AW, Kirby WM, Sherris JC, Turck M (1996) Antibiotic susceptibility testing by a standardized single disk method. Am J Clin Pathol 45: 493-496.

14. Khalil MM, Ismail EH, El-Baghdady KZ, Mohamed D (2014) Green synthesis of silver nanoparticles using olive leaf extract and its antibacterial activity. Arabian Journal of Chemistry 7: 1131-1139.

15. Zhang XF, Liu ZG, Shen W, Gurunathan S (2016) Silver nanoparticles: synthesis, characterization, properties, applications, and therapeutic approaches. Int J Mol Sci 17: 1-34.

16. Romero-Urbina DG, Lara HH, Velázquez-Salazar JJ, Arellano-Jiménez MJ (2015) Ultra structural changes in methicillin-resistant Staphylococcus aureus induced by positively charged silver nanoparticles. Beilstein J Nanotechnol 6 : 2396-2405. 